\title{
Dinamika Pengelolaan Sampah Rumah Tangga di Desa Gunung Sari, Kecamatan Citeureup, Kabupaten Bogor
}

\section{Domestic Wasted Management Dynamics at Households in Gunung Sari Village, Citeureup Subdistrict, Bogor District}

\author{
Francisca Gita Anjani $^{1}$, Pudji Muljono ${ }^{1}$ \\ ${ }^{1}$ Departemen Sains Komunikasi dan Pengembangan Masyarakat, \\ Fakultas Ekologi Manusia, Inatitut Pertanian Bogor, Bogor
}

\begin{abstract}
Domestic Wasted management program is one of PT Indocement's CSR conducted in Gunung Sari Village. This research aims on the evaluation of wasted management program that has been running since 2009. The evaluation was conducted using CIPP concept from Stufflebeam by analyzing content, input, process, and final product as an outcome from this program. This research illustrated both the supporting and inhibiting factors from the domestic wasted management program and also described the proceeding programs for these past 5 years. The population for this research was represented by 120 domestic house wives as corespondent, addressed in RW 04. Domestic wasted management program in Gunung Sari Village is running well. The supporting factors for this program are the subsidy cost from PT. Indocement CSR funds, the awareness of UPK management to be independent, creativity and the society's awareness for a cleaner environment. Meanwhile the inhibiting factors are the marketing for the final product and the lack of communications between the stakeholders.
\end{abstract}

Keywords: evaluation, CIPP, CSR, domestic wasted management

\section{Abstrak}

Program pengolahan sampah rumah tangga adalah salah satu program CSR PT Indocement yang dilaksanakan di Desa Gunung Sari. Penelitian mengevaluasi program pengolahan sampah yang telah berjalan sejak tahun 2009. Evaluasi program dilakukan menggunakan konsep CIPP dari Stufflebeam dengan menganalisis konten, input, proses, dan produk dari program ini. Penelitian ini menjelaskan faktor pendukung dan penghambat dari program pengolahan sampah rumah tangga. Populasi penelitian adalah ibu rumah tangga yang tinggal di RW 04 Desa Gunung Sari dengan jumlah responden sebanyak 120 orang. Program pengelolaan sampah rumah tangga di Desa Gunung Sari sudah berjalan dengan baik. Penelitian ini memberikan deskripsi bagaimana program pengolahan sampah rumah tangga sudah berjalan selama ini. Faktor pendukung yang mendukung berjalannya program adalah subsidi biaya dari CSR PT Indocement, kesadaran pengelola UPK untuk mandiri, kreativitas, dan kesadaran masyarakat untuk menciptakan lingkungan yang lebih bersih. Faktor penghambat dari program adalah pemasaran produk dan kurangnya komunikasi antar stakeholders.

Kata kunci: evaluasi program, CIPP, CSR, pengolahan sampah rumah tangga

\section{Pendahuluan}

Tanggung jawab sosial perusahaan atau lebih dikenal dengan Corporate Social Responsibility (CSR) merupakan sebuah konsep pengembangan masyarakat yang saat ini semakin populer diperbincangkan. Sebagai sebuah konsep yang semakin populer, The World Business Council for Sustainable Development mendefinisikan CSR sebagai komitmen dunia usaha untuk terus menerus bertindak secara etis, beroperasi secara legal dan berkontribusi untuk peningkatan ekonomi, bersamaan dengan peningkatan kualitas hidup dari karyawan dan keluarganya sekaligus peningkatan kualitas lokal dan masyarakat secara lebih luas. Konsep CSR berasal dari istilah 3P yang dikemukakan oleh John Elkington dalam Wibisono (2007) yakni mengenai pengintergrasian konsep 3P, yaitu keuntungan, lingkungan, dan masyarakat (profit, planet, dan people) dalam kegiatan perusahaan yang berkelanjutan. Pelaksanaan CSR di Indonesia juga diwajibkan dengan didasari UU Perseroan Terbatas No. 40 Tahun 2007 pasal 74, yang mengatakan setiap perseroan diwajibkan mengalokasikan sebagian laba bersih tahunan perseroan untuk melaksanakan tanggung jawab sosial dan lingkungan atau CSR.

Implementasi program Corporate Social Responsibility sangat bergantung pada cara setiap perusahaan memandang makna atau motivasi 
perusahaan dalam melaksanakan tanggung jawab sosial perusahaan. Kenyataannya, masih terdapat perusahaan yang hanya melihat program CSR dari perspektif ekonomi, sehingga kegiatan tersebut dimaknai sebagai program-program yang hanya menghabiskan dana perusahaan saja. Namun, ada juga perusahaan yang memandang program CSR dari segi goodwill yang memaknai setiap kegiatan berorientasi masyarakat yang didanai perusahaan sebagai program yang mampu menarik dan menumbuhkan simpati dari shareholders, investor, masyarakat luas, dan pihak lain yang terkait dalam kegiatan bisnis tersebut. PT. Indocement Tunggal Prakarsa Tbk (selanjutnya disebut PT. Indocement) merupakan salah satu perusahaaan yang sangat memperhatikan dan melaksanakan kegiatan CSR dengan baik. Hal ini didasarkan pada berbagai prestasi di bidang pelaksanaan CSR seperti Pelopor Pengembangan CSR Indonesia, Best Company in CSR 2013, dan Indonesia Social Responsibility Award2013.

Program CSR yang dilaksanakan PT Indocement didasarkan pada kebutuhan masyarakat agar tepat sasaran dan sesuai dengan kebutuhan masyarakat. Salah satu program CSR yang diterapkan adalah program pengelolaan sampah rumah tangga yang dilaksanakan di Desa Gunung Sari. Program ini merupakan jawaban dari permasalahan warga desa Gunung Sari yang memiliki permasalahan di lingkungan tempat tinggal mereka. Pesatnya pertumbuhan penduduk diikuti dengan peningkatan berbagai aktivitas ekonomi dan sosial masyarakat faktor yang menimbulkan berbagai masalah. Salah satu permasalahan yang timbul akibat semakin padatnya jumlah penduduk adalah meningkatnya volume sampah. Data dari Dinas Kebersihan dan Pertamanan Kabupaten Bogor, timbunan sampah Kabupaten dan Kota Bogor mencapai 6.456.891 m3/ hari dengan sisa sampah yang tidak dapat diangkut untuk Kabupaten Bogor sejumlah 5.165,501 m3/ hari. Desa Gunung Sari yang terletak di Kecamatan Citeureup, Kabupaten Bogor juga menjadi salah satu desa yang sampahnya tidak terangkut oleh angkutan sampah dari dinas. Sampah di Desa Gunung Sari tidak dapat diangkut karena jauhnya lokasi desa dari lokasi pembuangan dan kurangnya armada pengangkut sampah dari pemerintah sehingga masyarakat membuang sampah di lahan kosong sehingga menyebabkan permasalahan lingkungan. Melihat permasalahan yang dihadapi warga, perangkat desa bersama dengan tim CSR Departement PT. Indocement membuat program pengelolaan sampah rumah tangga.

Program pengolahan sampah rumah tangga di Desa Gunung Sari berjalan sejak tahun 2009 dengan dibangunnya Unit Pelayanan Kebersihan Gunung Sari dan pelatihan pembuatan kerajinan tangan di Mampang. Selama hampir lima tahun program ini berjalan secara dinamis yang melibatkan pihak-pihak untuk terlibat dalam program ini. Pelaksanaan program pengelolaan sampah ini tidak hanya melibatkan satu pihak, melainkan melibatkan masyarakat luas dan juga pihak lainnya hingga terbentuk dinamika kelompok. Dinamika kelompok adalah suatu kelompok yang terdiri dari dua orang atau lebih yang memiliki hubungan psikologis secara jelas antara anggota satu dengan yang lain dan berlangsung dalam situasi yang dialami (Mills, 1967).

\section{Masalah Penelitian}

Program pengelolaan sampah rumah tangga sudah berjalan sejak akhir tahun 2009. Program ini mengajak masyarakat untuk bersama-sama menjaga kebersihan lingkungan dan mengajarkan mereka tentang pengolahan sampah. Selama hampir lima tahun berjalan, banyak perubahan yang terjadi. Perubahan yang terjadi mulai dari perubahan kondisi lingkungan, perubahan pola pikir masyarakat dan juga perubahan dari sarana prasarana yang menunjang program tersebut. Perubahan-perubahan tersebut menjadi sebuah bahan bahasan untuk dilakukan evaluasi pelaksanaan program. Suatu program dalam proses pelaksanaannya memiliki tahapan evaluasi. Evaluasi dapat dilakukan sebelum program berjalan, saat program sedang berjalan (on going evaluation) atau saat program sudah selesai dijalankan. Proses evaluasi dibutuhkan untuk melihat sejauh mana tujuan program telah tercapai dan mengetahui perbaikan apa yang bisa dilakukan untuk ke depannya. Program pengelolaan sampah yang sudah berjalan hampir lima tahun dan melibatkan banyak pihak tentu memiliki banyak hal yang menarik untuk dievaluasi sehingga menjadi menarik untuk meneliti program pengelolaan sampah rumah tangga di Desa Gunung Sari.

Keberhasilan pelaksanaan suatu program 
tidak lepas dari dukungan faktor pendukung, begitu pula terdapat beberapa faktor yang dapat menghambat terlaksananya suatu program. Faktorfaktor tersebut bisa berasal dari perancang program, pelaksana program ataupun pihak dari luar. Begitu pula dengan faktor penghambat. Seringkali jika program kurang berhasil ditemukan faktor-faktor yang menghambatnya. Evaluasi program bertujuan membantu menemukan faktor pendukung dan penghambat pelaksanaan program agar dapat ditentukan langkah yang harus diambil selanjutnya. menarik untuk diteliti faktor-faktor apa saja yang mendukung dan menghambat pelaksanaan program pengolahan sampah di Desa Gunung Sari?

Faktor pendukung dan faktor penghambat tentulah mempengaruhi keberhasilan program. Faktor pendukung harus terus dikembangkan dan ditingkatkan agar program dapat terlaksana dengan baik. Faktor penghambat harus ditekan agar tidak menjadi penghalang dalam pelaksanaan program. Mengetahui faktor pendukung dan penghambat juga membantu pembuat keputusan untuk dapat mengambil keputusan dengan bijaksana sehingga menguntungkan semua pihak. Keputusan tersebut disesuaikan juga dengan kondisi yang ada di lapangan sehingga menjadi menarik untuk diteliti bagaimana strategi pengelolaan sampah di Desa Gunung Sari?

Penelitian bertujuan untuk mengevaluasi program pengelolaan sampah rumah tangga di Desa Gunung Sari, menganalisis faktor-faktor pendukung dan juga faktor-faktor penghambat dari program pengelolaan sampah rumah tangga di Desa Gunung Sari dan menganalisis strategi pengelolaan sampah di Desa Gunung Sari.

\section{Metode Penelitian}

Metode penelitian yang digunakan adalah metode penelitian gabungan (mixed methods) yang menggabungkan antara metode kualitatif dan kuantitatif. Tujuan menggunakan metode penelitian gabungan adalah memberikan analisi mendalam dengan data kuantitatif memperjelas dan membentuk data kualitatif (Sarwono, 2011).

Metode pengumpulan data dalam penelitian ini meliputi observasi non-partisipan, kuesioner dan wawancara mendalam. Populasi penelitian ini adalah warga RW 04, Desa Gunung Sari, Kecamatan
Citeureup sejumlah 600 keluarga. Sampel penelitian berjumlah $120 \mathrm{ibu}$ rumah tangga. Jumlah sampel ditentukan 20-25\% dari jumlah populasi (Arikunto, 2002). Data kuantitatif dari pengisian kuesioner diolah dengan tabel frekuensi kemudian dianalisis secara deskriptif. Data kualitatif dari wawancara mendalam dan observasi disajikan secara deskriptif untuk memperjelas dan memperkuat analisis dari data kuantitatif.

\section{Hasil dan Pembahasan}

\section{Pengelolaan Sampah Rumah Tangga di Desa Gunung Sari}

\section{Latar Belakang Program}

Pengelolaan sampah merupakan salah satu program CSR dari PT Indocement yang dilaksanakan di Desa Gunung Sari. Program pengelolaan sampah dilakukan di masyarakat dan di Unit Pelayan Kebersihan (UPK). Salah satu UPK yang sudah berjalan terdapat di Desa Gunung Sari, Kecamatan Citeureup. UPK ini berdiri dan mulai menjalankan program pengelolaan sampah sejak 23 Juli 2010. Program ini mengacu pada pembangunan millenium yaitu untuk meningkatkan keberlanjutan lingkungan dan juga mengacu pada isu global yaitu permasalahan bahan bakar fosil yang mahal dan langka. Pembentukan program pengelolaan sampah dan juga pembangunan UPK dilatarbelakangi masalah yang dihadapi warga desa binaan yaitu banyaknya sampah yang tidak terangkut dan sering terjadi keterlambatan pengangkutan sampah sehingga menimbulkan bau di wilayah pemukiman masyarakat. Selain itu, program ini juga dilatarbelakangi konsep pemberdayaan masyarakat dalam pengelolaan limbah rumah tangga dan juga untuk membantu pemerintah setempat dalam pengelolaan kebersihan.

\section{Tujuan Program}

Program ini meliputi kegiatan pengelolaan sampah rumah tangga yang dibagi menjadi sampah organik dan sampah non-organik. Sampah non-organik yang bisa dibuat produk daur ulang dikumpulkan oleh masing-masing rumah tangga. Sampah organik dan non-organik lainnya 
dikumpulkan di tong sampah yang telah disediakan untuk selanjutnya dibawa ke UPK untuk diolah menjadi kompos dan Sorted Municipal Wasted (SMW). Tujuan dari program pengelolaan sampah dan pembentukan UPK adalah:

1. Mengoptimumkan pengelolaan sampah menjadi produk yang bermanfaat, seperti pupuk cair atau padat, SMW, serta kerajinan rumah tangga.

2. Memberikan penghasilan tambahan bagi masyarakat yang terlibat langsung dan masyarakat luas pada umumnya dalam pengelolaan sampah tersebut.

3. Membantu menjalankan program pemerintah untuk mewujudkan lingkungan yang bersih, sehat, dan meningkatkan kesejahteraan masyarakat.

\section{Deskripsi Program}

Program pengolahan sampah merupakan program mengolah sampah rumah tangga menjadi produk bermanfaat yang dilaksanakan di Desa Gunung Sari, Kecamatan Citeureup. Sampah rumah tangga diolah menjadi produk daur ulang (kerajinan tangan), kompos, dan SMW. Kegiatan pembuatan produk daur ulang dilakukan oleh ibuibu RW setempat, dan pengolahan sampah menjadi kompos dan SMW dilakukan di UPK Gunung Sari. Masyarakat juga bisa mengumpulkan sampah yang bernilai jual seperti kardus, koran, gelas plastik dan botol di bank sampah yang ada di setiap RT. Sampah yang disetorkan di bank sampah akan ditimbang dan dicatat sehingga pada akhir bulan dapat diberikan uang hasil tabungan sampahnya.

Program Pengolahan Sampah merupakan salah satu Sustainable Development Program PT Indocement. CSR PT Indocement membantu dalam pembangunan UPK, memberikan modal berupa mesin pengolah sampah serta truk pengangkut, memberi pelatihan pengolahan sampah bagi pekerja UPK dan pembuatan kerajinan tangan bagi ibuibu UPPKS, dan memberikan fasilitas berupa tong sampah organik dan non organik bagi masyarakat yang sampahnya akan dikelola di UPK Gunung Sari. Masyarakat dilibatkan dalam proses pengelolaan sampah, selain melakukan pemilihan sampah organik dan anorganik, masyarakat dilibatkan dalam proses pembuatan produk daur ulang. Sampah plastik yang bisa dijadikan produk daur ulang dimanfaatkan dengan cara dikumpulkan lalu dibuat produk kerajinan yang bernilai jual. Sampah yang tidak bisa diolah dalam lingkup rumah tangga akan dibawa ke UPK untuk diolah menjadi SMW dan kompos. Secara lebih rinci program pengolahan sampah terdiri dari:

a. Pemilahan sampah organik dan anorganik. Output dari kegiatan ini adalah warga dapat membedakan sampah organik dengan sampah anorganik.

b. Daur ulang sampah anorganik merupakan salah satu upaya mengurangi jumlah sampah anorganik, seperti kemasan botol dan plastik untuk dibuat kerajinan. Output dari kegiatan ini adalah pengetahuan warga dalam membuat dan juga kerajinan tangan berbahan dasar sampah anorganik yang memiliki nilai jual.

Pengolahan sampah menjadi kompos dan SMW merupakan kegiatan yang dilakukan di UPK. Sampah yang telah dipisahkan warga menjadi sampah organik dan anorganik diangkat ke UPK dan diolah oleh pekerja UPK menjadi kompos dan SMW. Output dari kegiatan ini adalah kompos yang dapat dijual dan juga digunakan untuk proyek reklamasi dan SMW yang dijual ke perusahaan untuk dijadikan bahan bakar alternatif.

\section{Dinamika Pengelolaan Sampah Rumah Tangga di Desa Gunung Sari}

Pengelolaan sampah rumah tangga di Desa Gunung Sari dilakukan oleh beberapa pihak yaitu masyarakat RW 04, pekerja UPK Gunung Sari, pengurus UPPKS Pelita Hati dan department CSR PT Indocement. Masing-masing pihak tersebut membentuk kelompok sendiri yang memiliki tugas masing-masing. Masyarakat bertugas untuk memilah sampah menjadi sampah organik dan anorganik. Sampah anorganik yang memiliki nilai jual seperti kertas, koran, kardus dan kaca dapat mereka kumpulkan dan nantinya mereka tabung di bank sampah. Sampah kemasan plastik juga dapat dikumpulkan untuk dibuat kerajinan tangan. Sampah yang telah dipilah disetorkan ke bank sampah yang ada di setiap RT yang dikelola oleh pengurus RT masing-masing. Sampah yang dipilah lainnya yang akan dipergunakan untuk membuat kerajinan tangan akan dikumpulkan dan dikordinir oleh petugas dari UPPKS Pelita Hati. Sementara 
sampah yang tidak dipilah akan dibuang ke tempat sampah yang kemudian akan diangkut oleh petugas UPK Gunung Sari untuk di bawa ke UPK. Sampah yang telah tiba di UPK Gunung Sari diolah dengan menggunakan mesin crusher menjadi produk olahan sampah berupa kompos dan SMW atau bahan bakar alternatif.

Kegiatan pengelolaan sampah ini bersifat dinamis, dimana pihak-pihak yang terlibat saling berinteraksi dan membentuk relasi-relasi kelompok sosial.Kegiatanpengelolaannyajugaberkembangdan terus mengalami perubahan, tidak mengalami proses stagnasi sehingga merupakan proses yang dinamis. Seperti yang telah dijelaskan program pengelolaan sampah dilakukan di tiga pihak yaitu bank sampah, UPK Gunung Sari dan UPPKS Pelita Hati. Bank sampah tidak melakukan pengolah sampah menjadi sebuah produk. Bank sampah hanya sebuah tempat dimana warga dapat menabung sampah mereka yang kemudian sampah tersebut dijual kepada pengepul. Hasil penjualan nantinya diberikan kembali kepada masyarakat yang menabung pada akhir bulan. Proses Pengolahan sampah di UPK diawali dengan proses pengangkutan. Proses pengangkutan sampah dilakukan orang tiga orang pekerja dan satu orang supir dengan menggunakan truk. Setelah sampah diangkut, sampah dibawa ke UPK dan mulai diolah. Pertama-tama sampah dari truk dipindahkan ke bak sampah besar, kemudian dilakukan sortir dari batu, beling, dan plastik yang nantinya akan dijual ke pengepul. Kemudian dengan menggunakan belt conveyersampah dibawa pada mesin crusheruntuk dihancurkan. Setelah itu sampah disaring dengan cara diputar menggunakan screen. Sampah organik akan dibawa ke bak fermentasi untuk difermentasi menjadi pupuk sementara sampah anorganik akan dikemas dalam karung untuk dijual sebagai bahan bakar alternatif. Proses pengolahan sampah lainnya dilakukan oleh ibu-ibu yang tergabung dalam UPPKS Pelita Hati. Kegiatan pembuatan kerajinan tangan berbahan dasar sampah ini biasa dilakukan di Rumah Seni dan Budaya. Sampah yang telah disimpan dianyam menjadi kerajinan tangan yang dijual untuk menambah pendapatan masyarakat.

Pengelolaan sampah adalah semua kegiatan yang bersangkut paut dengan pengendalian timbulnya sampah, pengumpulan, transfer dan transportasi, pengolahan dan pemrosesan akhir atau pembuangan sampah, dengan mempertimbangkan faktor kesehatan lingkungan, ekonomi, teknologi, konservasi, estetika dan faktor-faktor lingkungan yang lainnya yang erat kaitannya dengan respon masyarakat. Kegiatan pengurangan meliputi pembatasan timbulan sampah, pendauran ulang sampah, dan pemanfaatan kembali sampah. Pengelolaan sampah di Desa Gunung Sari sudah melakukan kegiatankegiatan tersebut. Sebelum program dilaksanakan, hampir semua lahan kosong yang terdapat di RW 04 Desa Gunung Sari dijadikan lokasi untuk membuang sampah. Sampah menumpuk hampir di setiap sudut pemukiman. Kondisi yang demikian tidak lagi kita jumpai saat ini. Saat ini Desa Gunung Sari sudah lebih bersih. Masyarakat memiliki kesadaran yang tinggi untuk menjaga kebersihan di lingkungan sekitar tempat tinggal mereka.

Selama hampir lima tahun berjalan, program pengelolaan sampah banyak mengalami perubahan. Perubahan-perubahan yang terjadi mengarah pada kemandirian sosial. Seperti yang terjadi di UPK Gunung Sari, awalnya sarana dan prasarana yang ada di sana tidak seperti saat ini. Hanya ada mesin sangat sederhana untuk menghancurkan sampah, kondisi bangunan juga masih seadanya. Sekarang bangunan di UPK Gunung Sari sudah baik, terdapat kantor pengurus dengan fasilitas baik yang menggunakan pendingin ruangan, terdapat pagar-pagar yang membatasi area UPK, begitu pula dibangun bak-bak fermentasi. Perbaikan UPK Gunung Sari terus dilakukan. Saat ini UPK Gunung Sari sedang membangun green house.

Perjalanan program pengelolaan sampah di Desa Gunung Sari tidak selalu berjalan mulus. Bagaikan dinamika kehidupan, program pengelolaan sampah rumah tangga juga berjalan naik dan turun, seperti yang dijelaskan Ibu SOF, salah seorang warga RT 05:

\section{“...Kegiatan UPPKS pesertanya naik turun. Kalau lagi semangat ramai bisa sampai aula rumah seni penuh, tapi kalau sedang sepi ya seadanya bisa hanya belasan orang. Tapi yang penting ketika ada pesanan kami berusaha tidak mengecewakan..."}

Ada kalanya masyarakat begitu semangat dalam mengolah sampah mereka. Hal ini tergambar dalam pengolahan sampah menjadi produk kerajinan tangan yang dilakukan oleh ibu-ibu yang dikordinir 


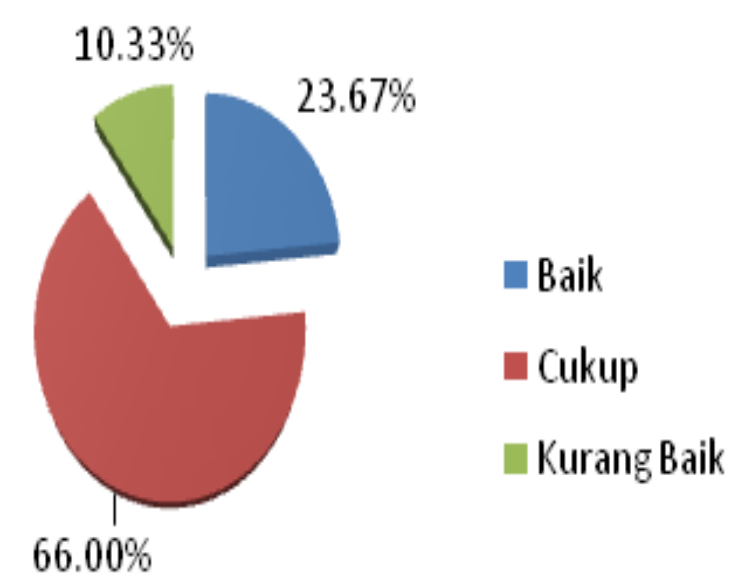

Gambar 2 Persentase Penilaian Masyarakat terhadap Kondisi SDM Program Pengelolaan Sampah Rumah Tangga

oleh pengurus UPPKS Pelita Hati. Ketika program baru berjalan dimana ibu-ibu baru mengikuti pelatihan pembuatan kerajinan tangan di Mampang, ibu-ibu begitu semangat berkumpul dan mengolah sampah rumah tangga mereka. Mereka rajin menggelar pameran-pameran untuk memasarkan hasil kerajinan tangan dari sampah. Ketika mendapat order ibu-ibu juga semangat untuk bersama-sama membuat kerajinan tangan. Semangat mengolah sampah juga terlihat dari jumlah sampah yang ditabung di bank sampah. Masyarakat berduyunduyun menabung sampah rumah tangga mereka.

Program pengelolaan sampah memang bersifat dinamis, sekitar tahun 2012 kegiatan Go Green banyak dilakukan masyarakat di kota-kota di Indonesia. Masyarakat bersama-sama melakukan kegiatan pengolahan sampah bahkan tidak sedikit yang juga membuat kerajinan tangan dari sampah. Kerajinan tangan dari sampah bukan lagi menjadi hal baru di Indonesia. Masyarakat mulai mengetahui bahwa sampah plastik bisa dibuat menjadi kerajinan tangan. Ketika itu program pengelolaan sampah di Desa Gunung Sari khususnya semangat ibu-ibu UPPKS Pelita Hati mulai mengendur. Semangat ibu-ibu kembali membara ketika UPPKS menjuarai lomba mengolah sampah tingkat Jawa Barat pada akhir tahun 2012, seperti dijelaskan Ibu VRG, ketua UPPKS Pelita Hati:

\section{“...Awalnya kami mengikuti lomba}

\begin{abstract}
di tingkat Kabupaten, Kemudian kami mencoba mengikuti lomba di tingkat provinsi. Membawa hasil kerajinan tangan yang sudah kami siapkan, kami presentasi bersama dan kami berhasil membawa piala juara satu! Kami semua bangga dan senang sekali..."
\end{abstract}

Prestasi tersebut kembali menyulut masyarakat untuk mengelola sampah rumah tangga mereka. Masyarakat bahkan memiliki motto "Sampah Membawa Berkah". Pengelolaan Sampah di Desa Gunung Sari sebagai salah satu program CSR PT Indocement sampai saat ini masih menjadi tanggung jawab PT Indocement. Hubungan pengelolaan sampah dengan konsep CSR adalah konsep 3P (People, Planet dan Profit). Konsep yang pertama adalah people, dimana program ini mengembangkan masyarakat di Desa Gunung Sari dengan memberikan pendidikan tentang pengolahan sampah pada masyarakat di desa mereka. Masyarakat Desa Gunung Sari menjadi memiliki pengetahuan tentang proses-proses mengolah sampah. Konsep yang kedua adalah planet, dimana program ini membantu menyelesaikan permasalahan lingkungan yaitu tentang sampah. Tumpukan sampah yang menjadi sumber penyakit sudah tidak kita jumpai sejak program berjalan. Lingkungan di Desa Gunung Sari juga menjadi lebih asri. Konsep yang ketiga adalah profit, dimana program ini membawa keuntungan baik dalam bidang ekonomi maupun

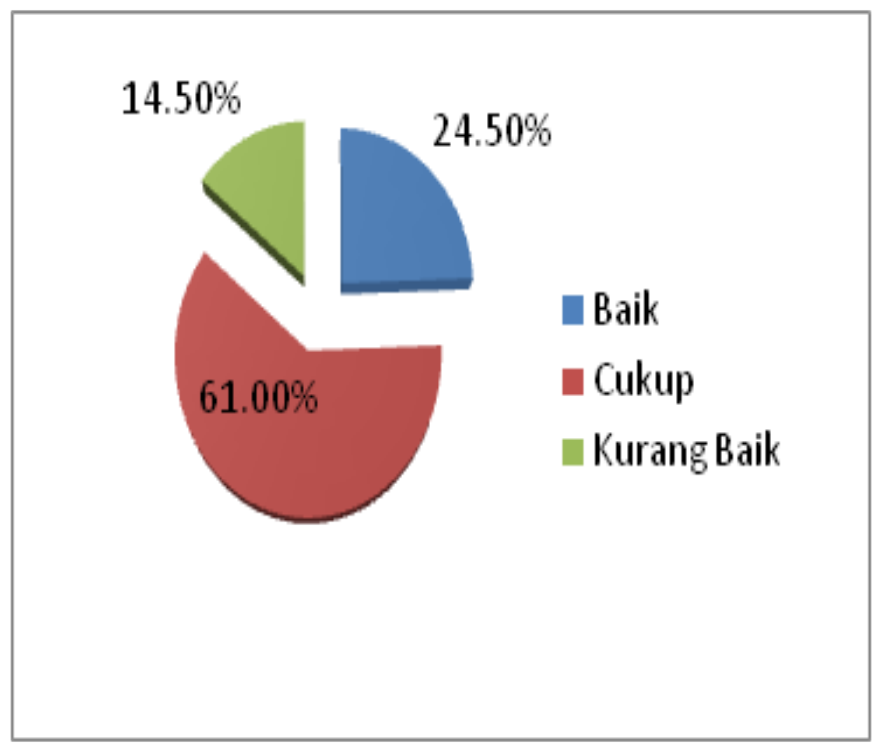

Gambar 3 Persentase Penilaian Masyarakat terhadap Kondisi Sarana dan Prasarana Program Pengelolaan Sampah Rumah Tangga 


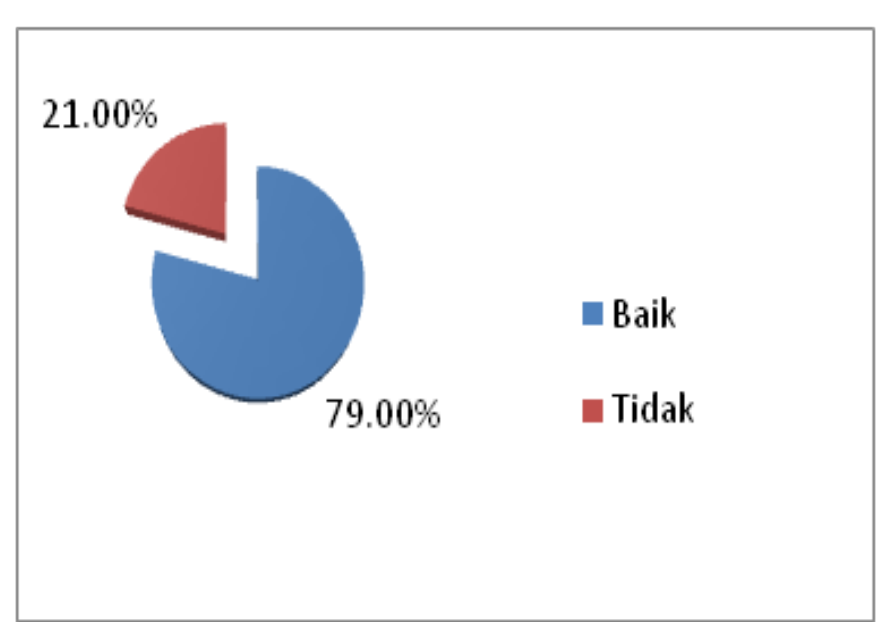

Gambar 4 Persentase Penilaian Masyarakat terhadap Mekanisme Pengangkutan Sampah Oleh Petugas UPK Gunung Sari

membawa citra positif bagi perusahaan. Program pengelolaan sampah rumah tangga merupakan program yang berkelanjutan seperti ciri program CSR dimana masyarakat sebaiknya diberikan program berkelanjutan yang nantinya mengarah pada kemandirian sosial.

\section{Evaluasi Program Pengelolaan Sampah Rumah Tangga}

Evaluasi program pengelolaan sampah rumah tangga di Desa Gunung Sari menggunakan pendekatan CIPP. Evaluasi menganalisis konteks program dengan mengukur sejauh mana keberhasilan program dalam mencapai tujuan yang telah ditentukan. Tujuan program pengelolaan sampah dan pembentukan UPK Gunung Sari yaitu (1) mengoptimumkan pengelolaan sampah menjadi produk yang bermanfaat, seperti pupuk, Sorted Municipal Wasted(SMW), serta kerajinan tangan, (2) memberikan penghasilan tambahan bagi masyarakat yang terlibat langsung dan masyarakat luas pada umumnya dalam pengelolaan sampah tersebut, (3) membantu menjalankan program pemerintah untuk mewujudkan lingkungan yang bersih, sehat serta meningkatkan kesejahteraan masyarakat, dan (4) meningkatkan pengetahuan masyarakat akan pengelolaan sampah rumah tangga.

Selama kirang lebih lima tahun program pengelolaan sampah sudah berjalan dan sudah dapat dlihat perubahan-perubahan positifnya. Lingkungan di RW 04 Desa Gunung Sari terlihat rapi dan bersih. Tidak ada sampah berserakan di jalan ataupun tumpukan sampah di lahan-lahan kosong. Ketika sore hari dapat pula dilihat masyarakat rajin menyapu halaman dan jalan depan rumah mereka. Kesadaran masyarakat akan kebersihan lingkungan tercermin oleh tindakan-tindakan tersebut. Ketercapaian tujuan program tentu didukung oleh input yang meliputi sumber daya manusia dan sarana prasarana pendukung, proses pelaksanaan yang baik dan juga dapat dilihat dari produk yang dihasilkan.

Hasil penelitian menunjukkan bahwa program pengelolaan sampah di Desa Gunung Sari sudah berjalan dengan baik. Tujuan program yang meliputi optimalisasi program untuk menghasilkan produk yang bermanfaat sudah berhasil diterapkan dengan dihasilkan produk kompos, SMW dan kerajinan tangan. Tujuan program lainnya yaitu mewujudkan lingkungan yang bersih dan sehat juga telah terwujud. Lingkungan Desa Gunung Sari setelah program berjalan, banyak mengalami perubahan menjadi lebih baik. Tidak lagi ditemukan tumpukan sampah pada lahan-lahan kosong, namun ada satu tujuan yang kurang tercapai yaitu peningkatan ekonomi masyarakat. Tidak semua masyarakat merasakan keuntungan secara ekonomi. Hanya masyarakat yang mau menabung di bank sampah dan terlibat membuat kerajinan tangan yang merasakan keuntungan ekonomi berupa pendapatan tambahan.

Input program dinilai memiliki kondisi yang cukup baik. Kondisi SDM yang terlibat dalam proses pengelolaan sampah di Desa Gunung Sari dinilai dengan persentase $66,00 \%$. Masyarakat merasa

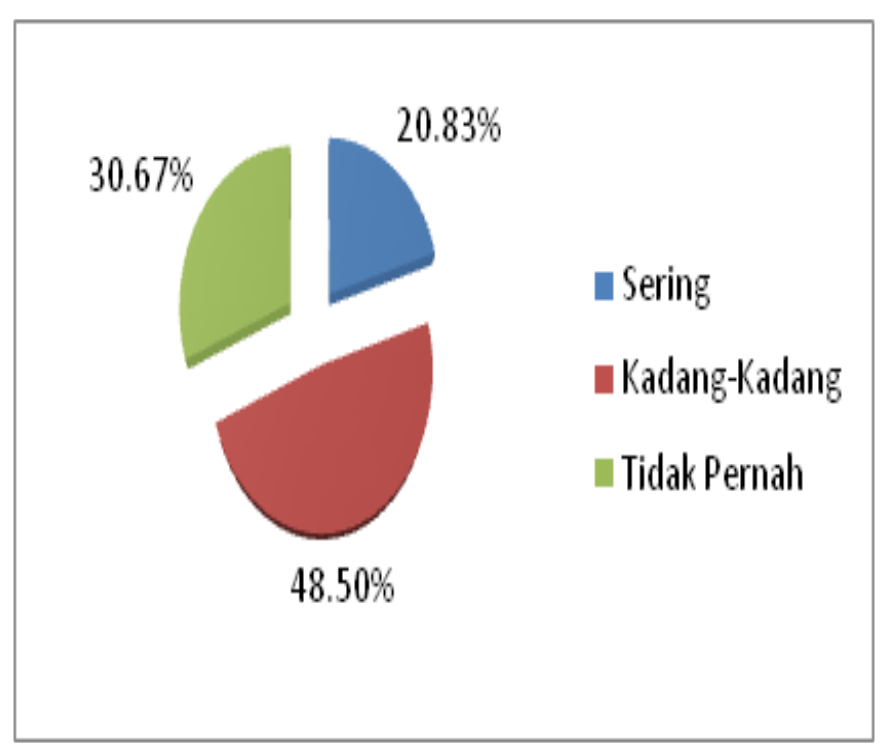

Gambar 5 Persentase Intensitas Masyarakat dalam Mengolah Sampah Anorganik 
kurang puas karena menurut masyarakat pekerja di UPK Gunung Sari tidak mengangkut semua sampah, padahal pihak UPK memang hanya melakukan tugas sesuai perjanjian yaitu hanya mengangkut sampah rumah tangga. Kondisi SDM yang baik mendukung keberhasilan program. Kesadaran masyarakat untuk mengikuti program dan juga keinginan mereka untuk menjadi masyarakat yang mendiri juga menjadi input positif dalam program (Gambar 2).

Sumber daya manusia dan kondisi sarana yang prasarana yang ada mendukung keberhasilan program. Salah satu sarana yang mendukung berjalannya program adalah tong sampah yang disediakan tiap rumah tangga. Kondisi sarana dan prasarana yang tersedia dinilai masyarakat dengan cukup baik.

Proses pelaksanaan program baik meskipun tidak semua responden mengolah sampah anorganik mereka secara langsung. Proses pengolahan sampah berjalan sesuai dengan apa yang kebutuhan masyarakat. Proses ini dibagi menjadi proses pemilahan sampah menjadi sampah organik dan non-organik, pengolahan sampah non-organik menjadi kerajinan tangan dan pengolahan sampah rumah tangga menjadi SMW dan kompos oleh Unit Pelayanan Kebersihan Desa Gunung Sari. Pembuatan kerajinan tangan berbahan dasar sampah non-organik dilakukan oleh ibu-ibu RW 04 yang dikordinir melalui Usaha Peningkatan Pendapatan Keluarga Sejahtera (UPPKS) Pelita Hati. Berbekal pelatihan keterampilan yang diadakan oleh CSR PT Indocement di kawasan Mampang pada tahun 2009, ibu-ibu mengembangkan kreativitas mereka untuk menciptakan berbagai macam kerajinan tangan dengan bahan dasar sampah non-organik untuk dapat dijual. Beberapa penghargaan berhasil didapatkan UPPKS Pelita Hati dalam kegiatannya membuat produk daur ulang. Hingga saat ini kegiatan pengolahan sampah non-organik masih terus dilakukan oleh ibu-ibu RW 04 Desa Gunung Sari.

Pengolahan sampah rumah tangga lainnya dilakukan oleh Unit Pelayanan Kebersihan (UPK) Gunung Sari. UPK Gunung Sari di bangun oleh PT Indocement pada tahun 2009 dan mulai beroperasi pada akhir tahun 2009. Proses pengolahan sampah di UPK Gunung Sari. Proses pengolahan sampah yang dilakukan UPK Gunung Sari diawali dari proses pengangkutan. Setelah sampah rumah tangga diangkut, dilakukan penyortiran secara manual. Penyortiran ini memisahkan sampah yang bisa dijual ke pengepul seperti sampah kaca dan plastik keras. Sampah yang tidak bisa dijual ke pengepul akan dibawa menggunakan belt conveyer untuk proses penghancuran dengan menggunakan mesin crushing. Selanjutnya akan dipisahkan antara sampah organik dengan non-organik dengan mesin penyaringan. Sampah organik akan difermentasi untuk dijadikan kompos sementara sampah nonorganik akan dibungkus untuk dijual sebagai sebagai bahan bakar alternatif / Sorted Municipal Wasted (SMW).

Produk kompos dan kerajinan tangan yang dihasilkan dari program ini dapat dimanfaatkan untuk warga. Namun manfaatnya belum cukup dirasakan oleh warga. Sedangkan untuk produk SMW tidak bisa bermanfaat langsung bagi warga namun menjadi salah satu pemasukan bagi UPK Gunung Sari. Masih dibutuhkan strategi-strategi agar program pengolahan sampah di Desa Gunung Sari semakin bermanfaat untuk warga. Mekanisme pengangkutan sampah yang dilakukan oleh petugas UPK Gunung Sari dinilai dengan persentase $79 \%$. Proses pengangkutan berjalan rutin seminggu dua kali dengan menggunakan truk UPK Gunung Sari. Masyarakat sangat terbantu dengan pengangkutan sampah yang dilakukan seminggu dua kali tersebut.

Proses pengolahan sampah yang dilakukan oleh ibu-ibu di RW 04 yang dikordinir dalam UPPKS Pelita Hati tidak melibatkan seluruh ibuibu. Meskipun tidak mengikuti proses pembuatan kerajinan tangan, masyarakat mengaku mereka seringkali diajak untuk bergabung. Kesibukan mereka mengurus rumah tangga ataupun bekerja yang membuat mereka tidak bisa berpartisipasi membuat kerajinan tangan. Kegiatan membuat kerajinan tangan juga tidak dilakukan setiap hari. Kegiatan dilakukan seminggu dua kali tergantung jumlah pesanan yang diperoleh. Persentase intensitas masyarakat dalam mengolah sampah anorganik digambarkan pada Gambar 5. Produk hasil program pengelolaan sampah adalah kerajinan tangan, kompos, dan SMW.

\section{Faktor yang Mempengaruhi Pelaksanaan Program}

Program pengelolaan sampah rumah tangga 
di Desa Gunung Sari masih terus berjalan dan sejauh ini perkembangan program menuju pada kemandirian sosial. Meskipun demikian untuk saat ini, program pengelolaan sampah di Desa Gunung Sari belum bisa mandiri secara ekonomi dan masih didukung oleh CSR PT Indocement. Setiap tahun, CSR PT Indocement masih memberi subsidi untuk menjalankan program ini. Meskipun UPK Gunung Sari sudah beroperasi dengan baik dan memproduksi kompos dan SMW namun masih belum bisa menutup biaya operasional. Dukungan subsidi dana tersebut setiap tahunnya menurun seiring dengan peningkatan produksi SMW dan kompos yang dapat dihasilkan UPK Gunung Sari.

Penurunan biaya subsidi dan peningkatan produksi menunjukkan bahwa kegiatan pengelolaan sampah di UPK Gunung Sari berjalan dengan baik dan berkembang setiap tahunnya. Penambahan area pengangkutan, penambahan alat produksi, dan pembangunan sarana di UPK menjadi program tahunan yang ditargetkan oleh pengurus UPK Gunung Sari namun seringkali menjadi kendala adalah miss communication antara warga dengan pihak UPK. Salah satu kejadian yang kerap terjadi adalah petugas ditegur bahkan pernah sampai menimbulkan konflik akibat warga yang merasa petugas pengangkut tidak mau repot mengangkut sampah yang besar seperti batang pohon dan puing bangunan. Warga tidak tahu bahwa berdasarkan pembagian tugas yang telah disepakati, petugas UPK Gunung Sari hanya bertugas mengangkut dan mengolah sampah sisa hasil konsumsi rumah tangga.

Perbedaan kepentingan juga menjadi faktor penghambat dalam mengembangkan program ini. Pihak UPK ingin ada kenaikan iuran warga sehingga bisa menutup biaya produksi dan tidak perlu bergantung dengan PT Indocement. Setiap bulannya, UPK Gunung Sari hanya memperoleh Rp 3.000.000 untuk mengangkut sampah dari 600 KK. Tentu saja nominal tersebut tidak cukup untuk menutup total biaya produksi dan upah petugas UPK. Sementara dari sisi masyarakat, mereka merasa bahwa program ini adalah program dari CSR PT Indocement sehingga tidak seharusnya meminta iuran dengan jumlah yang besar.

Kesadaran pengelola UPK Gunung Sari untuk berkembang menuju kemandirian menjadi salah satu faktor pendukung keberhasilan program pengelolaan sampah di Desa Gunung Sari. Setiap tahunnya dilakukan perubahan dan perkembangan untuk kemajuan UPK Gunung Sari. Perubahan tersebut meliputi penambahan alat seperti mesin crusher, pembuatan bak fermentasi dan saat ini sedang dibangun green house. Wilayah pengangkutan sampah juga bertambah, awalnya UPK Gunung Sari hanya mengangkut sampah di RW 04 Desa Gunung Sari. Saat ini UPK Gunung Sari juga mengangkut sampah dari perumahan Gunung Putri Permai dan Bumi Citeureup Asri. Harapan warga dan juga pihak UPK wilayah pengangkutan dapat diperluas lagi hingga seluruh Desa Gunung Sari.

Kendala lain yang dihadapi UPK Gunung Sari adalah masalah pemasaran produk. Saat ini memang produk yang dihasilkan lebih banyak dijual ke PT Indocement, harapannya produk seperti kompos dapat dijual ke pasaran lebih luas. Begitupula dengan produk SMW bisa dijual ke perusahaan lain selain Indocement. Untuk produk SMW sendiri kendala yang dihadapi adalah untuk saat ini hanya PT Indocement yang memiliki tekhnologi untuk menggunakan SMW menjadi bahan bakar alternatif sehingga untuk saat ini memang pasar produk SMW sebatas PT Indocement.

Kendala pemasaran juga dihadapi oleh UPPKS Pelita Hati. Kerajinan tangan hasil dari olahan sampah semakin terkenal di masyarakat sehingga banyak pula kelompok yang membuat kerajinan serupa. Ibu-ibu anggota UPPKS harus terus kreatif dan berkreasi agar tetap bisa bertahan di tengah persaingan yang ada. Pemasaran yang lebih kreatif dan luas juga harus dilakukan oleh bagian pemasaran dari UPPKS Pelita Hati.

Sarana dan prasarana juga menjadi faktor yang mempengaruhi pelaksanaan program. Sarana dan prasarana yang buruk tentu akan menghambat keberhasilan program. Setelah berjalan selama sekitar lima tahun, sarana yang digunakan tentulah membutuhkan perbaikan. Salah satu sarana penting yang harus diperbaiki adalah tong sampah. Seperti hasil pengamatan yang saya lakukan, kondisi tempat sampah warga sudah banyak yang rusak. Tong sampah pecah bahkan hancur masih tetap digunakan oleh warga. Beberapa warga mengganti tong sampah dengan menggunakan, tong bekas cat atau wadah besar yang bisa digunakan menampung sampah. Kondisi ini cukup menyulitkan petugas pengangkut dalam mengangkut sampah. Selain itu tong sampah yang rusak membuat sampah berceceran dan 
memberi kesan tidak rapi. Warga berharap agar mendapat bantuan tempat sampah lagi seperti pada awal program dijalankan.

\section{Strategi Pengelolaan Sampah di Desa Gunung Sari}

Pengelolaan Sampah di Desa Gunung Sari bisa berjalan sejauh ini berkat adanya keinginan dari tiap stakeholders yaitu warga desa, pihak UPK, dan pihak PT Indocement untuk menciptakan lingkungan yang bersih di Desa Gunung Sari. Kesamaan tujuan inilah yang membuat semua pihak melakukan tugas dengan baik. Masyarakat membuang sampah pada tempatnya, membayar iuran, berpartisipasi menabung di bank sampah dan membuat kerajinan tangan dari sampah. UPK Gunung Sari juga melakukan tugas mereka dengan baik, yaitu mengangkut sampah rumah tangga dan mengolah sampah rumah tangga menjadi produk yang bermanfaat. Begitu pula dengan PT Indocement yang tidak lepas tangan setelah membuat program. CSR PT Indocement tetap melakukan monitoring dan membantu baik dari sisi dana maupun memberi fasilitas serta perawatan mesin meskipun program ini sudah berjalan sejak lama, namun belum ada kekompakan antar pihak yang terlibat

Program pengolahan sampah rumah tangga merupakan program yang membutuhkan kerjasama dan kekompakan antarpihak, sehingga bisa saling mengerti permasalahan antar bagian. Saat ini program pengolahan sampah pecah menjadi bagianbagian sendiri. UPK Gunung Sari hanya mejalankan tugas mereka tanpa mendapat perhatian lebih dari warga. Perlu dirancang sebuah manajemen yang membawahi kegiatan-kegiatan pengelolaan sampah di Desa Gunung Sari sehingga terjalin komunikasi yang baik antarpihak. Dengan adanya komunikasi yang baik antarpihak diharapkan dapat mengerti masalah-masalah yang dihadapi dan dapat mencari solusi secara bersama-sama.

Terkait dengan permasalahan pemasaran produk, pemasaran produk memang seringkali menjadi masalah dalam setiap aktivitas produksi. Kebijakan yang dilakukan oleh UPPKS Pelita Hati sudah cukup bijaksana dimana mereka akan melakukan produksi sesuai dengan pesanan yang ada. UPPKS Pelita Hati juga memiliki pengurus yang bertugas memasarkan produk. Pemasaran produk bisa coba dilakukan dengan memanfaatkan media sosial seperti facebook dan instagram. Dengan meningkatnya jumlah pesanan, jumlah warga yang terlibat dalam proses pembuatan juga akan semakin banyak.

Perbaikan dan perawatan sarana dan prasarana juga harus dilakukan. Perawatan mesin UPK Gunung Sari dilakukan dengan baik dan bila terjadi kerusakan PT Indocement akan dengan cepat membantu memperbaiki mesin tersebut. Perbaikan perlu dilakukan untuk sarana tong sampah. Tong sampah yang sudah tidak layak sebaiknya diganti. Untuk tong sampah sebaiknya disediakan tong sampah yang bertutup agar isi tong sampah tidak tergenang air sehingga membuat tong sulit diangkut.

Program berjalan dengan baik sehingga menciptakan lingkungan yang lebih bersih sudah tercapai, namun pemilahan sampah belum berjalan. Pemilahan sampah akan bermanfaat jika dilakukan secara kompak, kalau perlu dibuat peraturan tertulis untuk pemilahan sampah. Perlu sosialisasi lanjutan pemilahan sampah organik dan non oraganik dilengkapi dengan sarana yaitu dua buah tong sampah. Proses pemilahan sampah harus dilakukan secara konsisten dan harus kompak dilakukan oleh warga maupun oleh pihak UPK dalam proses pengangkutannya. Sosialisasi penting dilakukan untuk meningkatkan kesadaran masyarakat agar mau memilah sampah. Sosialisasi bisa dilakukan lebih dari satu kali sesuai dengan kondisi dan tanggapan dari masyarakat.

\section{Kesimpulan}

Program pengolahan sampah rumah tangga di Desa Gunung Sari berjalan dengan baik. Segi konten yang dibuat sudah sesuai dengan tujuan, kebutuhan dan sasaran yang ingin dicapai. Input program yang meliputi kondisi sumber daya manusia dan kondisi sarana prasarana cukup baik. Perlu ditingkatkan untuk kondisi sarana yaitu perbaikan tong sampah. Proses yang dilakukan sudah cukup baik dengan pengangkutan dilaksanakan dengan rutin dan program pengolahan sampah nonorganik menjadi kerajinan tangan juga cukup baik dilaksanakan walaupun belum merata hingga dapat mensejahterakan masyarakat.

Program pengolahan sampah rumah tangga menghasilkan produk yaitu kompos, kerajinan 
tangan dan SMW. Untuk produk kerajinan tangan dinilai bermanfaat bagi masyarakat dan untuk kompos masih dinilai kurang bermanfaat bagi masyarakat. Produk lainnya yaitu SMW terus mengalami peningkatan produksi setiap tahunnya. Tujuan program sudah terlaksana, meskipun belum dinikmati secara merata oleh seluruh masyarakat. Tahapan pemilahan sampah organik dan nonorganik yang seharusnya dilakukan di rumah tangga masing-masing. Pemilahan sampah belum berjalan di RW 04 hal tersebut karena masih kurangnya kesadaran masyarakat untuk memilah sampah. Perlu diadakan sosialisasi untuk meningkatkan kesadaran masyarakat agar masyarakat mau memilah sampah rumah tangga mereka.

Terdapat faktor pendorong dan penghambat yang sangat mempengaruhi keberhasilan program. Faktor pendorong dalam program pengolahan sampah rumah tangga adalah subsidi biaya produksi dari CSR PT Indocement, kesadaran untuk mandiri dari pelaku program di UPK Gunung Sari dan pengembangan inovasi. Sedangkan untuk faktor penghambat yang dapat menghambat program adalah kurangnya komunikasi yang berpotensi menyebabkan konflik, persaingan dari pihak lain dan keterbatasan pasar.

Hal yang dapat menjadi strategi untuk meningkatkan program pengelolaan sampah adalah menjalin komunikasi yang baik antar stakeholders dengan membuat satu managemen yang mewadahi kegiatan pengolahan sampah secara keseluruhan. Manajemen tersebut menyatukan masyarakat, UPK Gunung Sari dan UPPKS Pelita Hati sehingga komunikasi dapat terjalin dengan baik. Komunikasi antar stakeholders dapat dilakukandengan membuat forum komunikasi sehingga tidak ada lempar tanggungjawab apabila terjadi masalah. Komunikasi yang baik juga akan membantu menciptakan kondisi saling memahami yang dapat meredam konflik.
Strategi lainnya adalah strategi pemasaran yang bertujuan untuk memperluas pasar hasil produk pengelolaan sampah baik itu kompos maupun kerajinan tangan dengan luas area pemasaran dapat meningkatkan jumlah permintaan sehingga produk yang dijual pun akan meningkat.

\section{Pustaka}

Arikunto S. 2002. Prosedur Suatu Penelitian: Pendekatan Praktek. Jakarta (ID): Rineka Cipta. Crawford JH. 2003. Composting of Agricultural Waste in Biotechnology Applications and Research. Bogor (ID): Balai Penelitian Bioteknologi Perkebunan Indonesia.

Dinas Kebersihan dan Pertamanan Kota Depok. 2007. Kajian Pengelolaan Persampahan Kota Depok. Depok (ID): DKP.

Departemen Pendidikan Nasional. 2010. Kamus Besar Bahasa Indonesia. Jakarta (ID): Gramedia Pustaka Utama.

Hadiwiyoto S. 1983. Penanganan dan Pemanfaatan Sampah. Jakarta (ID): Yayasan Idayu.

Kastaman R, Kramadibrata AM. 2007. Sistem Pengelolaan Reaktor Sampah Terpadu (Silarsatu). Bandung (ID): Humaniora.

Mills TM. 1967. The Sociology of Small Groups. New Jersey: Prentice Hall Inc.

Rosa AR. 2009. Evaluasi Program Komposting Sampah Rumah Tangga. [Skripsi]. Bogor: IPB.

Sarwono J. 2011. Mixed Methods. Jakarta (ID): Elex Media Komputindo.

Wibisono Y. 2007. Membedah Konsep dan Aplikasi CSR (Corporate Social Responsibility). Gresik (ID): Fascho Publishing.

Winardi J.2007. Manajemen Perilaku Organisasi. Jakarta (ID): Kencana.

WidoyokoEP.2010.Evaluasi ProgramPembelajaran. Yogyakarta (ID): Pustaka Pelajar. 